\title{
Failed intentions? Meeting the water needs of people living with HIV in South Africa
}

\author{
Mary Galvin' and Linah N Masombuka² \\ 'Department of Anthropology and Development Studies, University of Johannesburg, Johannesburg, South Africa \\ ${ }^{2}$ Department of Communication Science, University of South Africa, Pretoria, South Africa
}

\begin{abstract}
Researchers, activists, practitioners and policy-makers have grappled with the challenge of providing people living with HIV (PLHIV) with an adequate amount of safe water. Comprising 13\% of the overall population of South Africa in 2018, 7.52 million PLHIV need water for drinking and taking medication; preparing food; and personal hygiene and cleaning to minimise infections. This article examines the responses of the different stakeholders to this challenge and their impact on the water and health policy process. It finds that activists were able to emphasise the dimensions of the challenge; practitioners worked to implement provision more effectively within existing policy frameworks; and a range of stakeholders made a thoughtful and promising policy proposal for direct action, which the Department of Water and Sanitation ultimately failed to embrace. This article is based on an extensive review of academic research and publications by development agencies on HIV and water as well as engagement with policies and documents in the South African water sector related to water services delivery for PLHIV. While the widespread provision of antiretrovirals from 2004 has changed the context, the above findings are significant in understanding and reviewing the impact of various stakeholders on the water and health policy process. They raise questions regarding the effectiveness of NGO advocacy, the means of delivering improved services to specific populations, and the ability of a range of stakeholders to inform the policy approaches of government departments.
\end{abstract}

\section{CORRESPONDENCE}

Mary Galvin

\section{EMAIL}

mgalvin@uj.ac.za

\section{DATES}

Received: 19 February 2019

Accepted: 3 April 2020

\section{KEYWORDS}

activist

HIV

multi-stakeholder

targeting

water

\section{INTRODUCTION}

Access to water is a human right of all people and, prior to the widespread access to antiretrovirals (ARVs), was a critical need of people living with HIV (PLHIV). The compromised immune systems of PLHIV and their susceptibility to contracting opportunistic infections meant that clean water was essential for drinking and taking medication; preparing food; personal hygiene and cleaning to minimise infections; and for mothers to prepare baby formula. Fortunately, ARVs not only reduce the HIV viral load to almost undetectable levels, but also improve immune functioning and reduce opportunistic infections. As a result of most PLHIV having access to ARVs, the need to focus specifically on providing an additional quantity of clean water to PLHIV has become less pressing.

Yet the experience of a policy challenge of this magnitude provides important lessons for the water sector. The aim of this article is to examine the responses of different stakeholders - researchers and activists, practitioners and policy makers - to the challenge of providing an adequate amount of clean water for PLHIV in South Africa and their impact on the water and health policy process. Considering each of the three stakeholder groups in turn, it focuses on how their response developed and what we can learn from this process.

It argues that while activists used limited research to formulate a straightforward position that PLHIV need $100 \mathrm{~L}$ of water per day, practitioners in South Africa grapple with the complex realities of water systems that either do not exist or are not functioning, and focus on making systems functional. In this context, formulating a policy to deliver additonal water to an estimated 7.52 million PLHIV in South Africa (Statistics South Africa, 2018) brought difficult issues to the fore. Questions arose about how to provide additional water to some people and not others in an area, how government might cover the cost of additional water, and how the challenge of providing an increased quantity of water to PLHIV can be taken up when basic water provision has not yet been achieved for all. While a range of stakeholders may have been well-intentioned in formulating a thoughtful and promising policy framework for adoption, those making policy within Government were constrained by finances and internal power dynamics and did not do so. This article shows that, in spite of various stakeholders' commitments to meet the water needs of PLHIV, typical considerations of provision continue to affect delivery to all users, with no specific approach to increase provision to PLHIV.

Academic research in the area of HIV and water has been limited. It focuses largely on the health, gender or psycho-social impacts of poor quality or inadequate quantity of water, often based on quantitative work in specific areas (De la Porte, 2011; Aketch, 2017; Workman and Ureksoy, 2016). In contrast, this article approaches HIV and water from the 'water side of the equation', considering the delivery of water in different types of geographical areas and examining how the need for an improved supply of water intersects with typical considerations of water practitioners and 
policy makers: level of service and affordability. By considering these issues in terms of policy formulation, it avoids abstract discussion, which is a weakness of much existing literature.

This article is based on an extensive review of available academic literature on the relationship between water and HIV generally and in South Africa, found in 20 international databases (Table 1), as well as 'grey literature' produced by non-governmental organisations (NGOs) and donors. Utilising internet sources and personal networks, the authors obtained relevant South African policy and programme documents. The research is also informed by the first author's work in the South African water sector as a researcher and development practitioner over the past two decades.

The three sections of this article build on one another. The first section examines how the water needs of PLHIV have been defined by researchers and activists through a focus on quantity. The second section expands this discussion by considering the implementational realities that shape practitioners' engagement with improving access to water: service level and affordability. Finally the third section considers policy making and how the needs of PLHIV have been promoted (or not) in existing policies and plans in South Africa. It discusses how a specific strategy for implementation was sidelined. After examining how different stakeholders have engaged with the need to meet the water needs of PLHIV, the article concludes by highlighting areas for research that would strengthen the ability of the sector to meet such challenges in the future.

\section{Researchers and activists: measuring the water needs of PLHIV}

The main rationale behind the efforts to define the physical water needs of PLHIV is the devastating impact that inadequate and unsafe water has on PLHIV. Without adequate, safe water, hygiene is compromised; this can cause or exacerbate diarrhoea, further weakening PLHIV and compromising their immunity. This can also put carers and other household members at risk of illness. According to WaterAid (2004, p. 2):

People living with HIV/AIDS need as much protection from disease as possible. Because of their debilitated immune system they are highly susceptible to communicable diseases and infections, including those that are water and hygiene related. Minor diarrhoea, typhoid or typhus can all prove fatal for someone weakened by HIV/AIDS. The provision of a safe and adequate water supply can help prevent exposure to such illnesses.

Other waterborne diseases caused or worsened by poor quality water that pose a significant threat to PLHIV include cholera, hepatitis, dengue fever, malaria, and other parasitic diseases (Ramirez-Ortiz and Zolnikov, 2016).

The impact of diarrhoea, a manifestation of waterborne infections, is particularly devastating for PLHIV and their households. Relative to uninfected populations, diarrhoeal rates in PLHIV are 2 to 6 times higher, and acute and persistent diarrhoeal rates are twice as high (Lule et al., 2005 in Bery and Rosenbaum 2010). These impacts are particularly acute in Africa, where $90 \%$ of HIV-positive people suffer from chronic diarrhoea (Bery and Rosenbaum, 2010). In addition to reducing the quality of life of PLHIV, diarrhoeal illness can speed the progression from HIV to AIDS and can interfere with and compromise the absorption of these ARV drugs and can even contribute to developing HIV strains that are resistant to antiviral agents' (Bushen, 2004 in Bery and Rosenbaum, 2007). Another danger is that, without safe water to mix infant formula, babies are at greater risk of contracting diarrhoeal diseases that can result in
Table 1. Databases searched for HIV and water articles

\begin{tabular}{l}
\hline Database \\
\hline Academic Onefile \\
Brill Online Journals \\
Cambridge Journals \\
De Gruyter Journals Online \\
EBSCOhost \\
ISI Web of Science \\
JSTOR \\
OECD iLibrary \\
Oxford Journals Online \\
Project Muse \\
Proquest Dissertations and Theses \\
SAePublications \\
Sage Journals Online \\
ScienceDirect \\
Scopus \\
SpringerLink \\
Taylor \& Francis Online \\
Wiley \\
World Bank E-Library \\
OpenDoor (Directory of Open Access Repositories) \\
\hline
\end{tabular}

death (Bery and Rosenbaum, 2007).

The use of water, sanitation and hygiene (WASH) practices hand washing, sanitation, water treatment and safe storage have each been proven to reduce diarrhoeal rates by $30-40 \%$ and prevent caregivers and other household members from contracting water-related diarrhoeal diseases (Curtis and Cairncross, 2003; Fewtrell et al., 2005; Clasen et al., 2007). Not only does a healthy household prove more 'more economically viable', but it is also more resilient against the challenges of HIV (Bery and Rosenbaum, 2010, p. 1).

When water quality is considered, 'clean' water is often used interchangably with 'safe' drinking water, which is defined as being 'free from pathogens and elevated levels of toxic chemicals at all times'. Typically the delivery of safe water is measured through access to improved water sources, including household connections, public standpipes, boreholes, protected wells or springs, rainwater or tankered water; this article refers to the level of service above basic access. It is clear that people who lack access to water and draw water from contaminated sources are using unsafe water, and need to use home-based water treatment and safe water handling. However it is important to note that water from improved sources or even treated water may still not be safe to drink. Residents who have been supplied with water but are serviced by ill-managed or failing wastewater treatment plants are at risk (Richie and Roser, 2020).

Given the importance of PLHIV having clean water as well as an adequate amount, one of the top priorities has been to quantify the amount of water needed. The quantity aspect of water can be understood as the level of water access and volumes that people have or are meant to have (Howard and Bartram, 2003). The literature on water and HIV asserts frequently that PLHIV require more water than the basic access of 20-25 L per person per day specified by the World Health Organisation (WHO), on which South Africa's free basic water amount is based, to meet their additional hygiene needs (WHO, 2003).

In the 2010s, stakeholders including NGOs such as WaterAid, Southern Africa HIV and AIDS Information Dissemination Service (SAfAIDS) and the WHO formulated their advocacy strategies around the position that PLHIV require $100 \mathrm{~L}$ of water per day (SAfAIDS and WaterAid Southern Africa, 2014; WHO, 2010). This amount has been reported extensively in the news, notably by The Guardian and Reuters (Frost et al., 2014; Mis, 2014; Gosling, 2015), and has arguably become 'common 
knowledge' on the subject of HIV and water that is widely cited by policy makers and practitioners (UNAIDS, 2004; Kamminga and Wegelin Schuringa, 2005; Potter and Molose, 2005; Ngwenya and Kgathi, 2006; Potter and Clacherty, 2007; WHO, 2010; SAfAIDS and WaterAid Southern Africa, 2014).

We found that their position is made on the basis of limited research and is not based on a generalisable sample; it draws from three sources that independently state that up to $100 \mathrm{~L}$ of water per day is needed by PLHIV for domestic use:

- Depending on the severity of symptoms, a case study in Botswana indicated that an additional $20-80 \mathrm{~L}$ of water could be required daily for PLHIV (Ngwenya and Kgathi, 2006). Taking the $80 \mathrm{~L}$ of additional water (high end estimate), plus the basic supply of $20 \mathrm{~L}$, we reach $100 \mathrm{~L}$.

- A rural woman interviewed as part of a case study conducted in southern Africa estimated that it requires 24 buckets of water a day to wash a PLHIV and their clothing, bedding and the house, especially during bouts of extreme diarrhoea (Kamminga and Wegelin Schuringa, 2005; UNAIDS, 2004). For a bucket capacity of just over $3 \mathrm{~L}$, this would mean that, together with 20-25 L basic supply, we reach nearly $100 \mathrm{~L}$.

- Home-based caregivers surveyed in South Africa estimated a need for $200 \mathrm{~L}$ of water daily, including water needed for income-generating activities and food production (Potter and Molose, 2005; Potter and Clacherty, 2007, p. 21). If $100 \mathrm{~L}$ of this water is allocated for income-generating activities and food production, this leaves $100 \mathrm{~L}$ for domestic use.

It is important to note that these studies are not based on a robust method that allows for generalisation. Two of these sources rely on case studies, one in southern Africa in general and the other in Botswana. The South African survey, on the other hand, captures a broader range of experiences; however its focus on income-generating activities limits what can be concluded regarding the water required for PLHIV.

In turn, the pre-eminent global health authority, the WHO (2010), draws on the same sources to compile a table that breaks down the water needs of PLHIV (Table 2). The broad headings in Table 2 include a range of caregivers' needs (Potgieter et al., 2008, p.vi):

...hand washing, bathing the patients, brushing their teeth, cleaning the dwelling and the yard, the toilet, to do the laundry, for drinking, cooking and preparing food. They also used it for medical purposes such as drinking medication, cleaning wounds and keeping the patients and their environment hygienic to improve the lives of the patients and to have a positive impact in a given community.

What is most striking from Table 2 and this description is that the last need, of cleaning, consumes most of the additional water that is required, and that this amount is highly variable.

Some analyses discount the $100 \mathrm{~L}$ amount, asserting that 'current estimates of water requirements are highly variable (from 50 to $200 \mathrm{~L}$ and more per person) but there are no tangible data to confirm this' (Makaudze et al., 2012, p. 66). Variability or 'heterogeneity of use' is illustrated by Mbereko et al. (2016)'s case studies in rural Zimbabwe, in which they capture people's experiences of water scarcity in accessing between 40 and $240 \mathrm{~L}$ per day. This provides a rich and important socio-political and cultural context that is typically overlooked. However in their attempt to move to quantifying people's 'perceived water needs' and then to use this to reach a pseudo-scientific measure of overall 'water shortage', they overlook important usage factors. These include their typical or 'base' usage rate (to which the additional quantity of water required is added) and their usage habits. In other words, comparable households that use water for
Table 2. Basic water needs of PLHIV (Source: WHO, 2010, p. 4)

\begin{tabular}{ll}
\hline Water need & Water required \\
\hline Basic water for drinking, food & $20 \mathrm{~L}$ per day (recommended \\
preparation, laundering and & minimum)
\end{tabular}
personal hygiene Water for taking antiretroviral Additional $1.5 \mathrm{~L}$ per day
medications

Water for replacement feeding of Minimum $1 \mathrm{~L}$ per day (without infants under 6 months water needed for cleaning)

Water for replacement feeding of $2 \mathrm{~L}$ per day (without water infants over 6 months needed for cleaning)

Cleaning PLHIV and laundering $\quad$ 20-80 L per day ${ }^{\mathrm{a}}$

clothes and bedding (daily

during bouts of diarrhoea)

Total

Approximately $100 \mathrm{~L}$ per day

${ }^{a}$ Depending whether or not the patient is under antiretroviral treatment Data sources: Ngwenya and Kgathi, 2006; Potter and Molose, 2005; WSP, 2007

the same purposes may differ significantly in their estimate of their needs. (And they may have an understandable incentive to report high levels of need.)

As shown above, researchers' attempts to quantify the amount of water needed by PLHIV are not reliable, due to differences in particular contexts and specific cases; however they are useful as a means for those advocating adequate, clean water for PLHIV to increase pressure for policy change and programme implementation. Groups advocating adequate access to water for PLHIV can use the clear demand of $100 \mathrm{~L}$ to appeal to policy makers. This is then supported with detail about how it improves the quality of life and health of PLHIV, eases the physical burden of accessing water, and frees up time that can be used socially and to build HIV awareness (Ramirez-Ortiz and Zolnikov, 2016).

So, despite the weak basis for this claim and its lack of contextualisation, the WHO is willing to rely on the present data in its publications, using it to make a clear statement that governments should take into account that PLHIV need up to 4 times the quantity of water accepted as the WHO standard for basic access. The WHO's statement has the potential to raise awareness and build political will to ensure the water needs of PLHIV are incorporated into policy and programmes. As a powerful, globally respected authority, its statements can be influential with national policy makers.

While such advocacy is important, any undertaking that is secured will depend on the ability of practitioners to deliver an increased amount of quality water within the present policy framework and functioning of the water sector. The following section reviews how the level of service differs by residential area and, alongside the affordability of water, determines the quantity of water that people can access in South Africa.

\section{Practitioners: Facing the challenges of providing water services}

The legacy of apartheid is visibly apparent in two factors that affect people's access to water: where people live as well as the struggle of new municipalities to develop their capacity to extend and provide services universally. First, people's access to water, in terms of its availability and reliability, depends on a household's location; while residential location under apartheid was racially based, it is now perpetuated in terms of class. Second, while there have been extensive efforts to build capacity in the water sector, particularly at the municipal level, there are still significant differences in delivery of water services between 
municipalities. These differences are detailed in the municipal benchmarking reports compiled by the South African Local Government Association (SALGA, n.d). This section discusses the differences in provision across geographical areas and some of the determinants of water quantity that pose a challenge to municipalities.

While activists call for $100 \mathrm{~L}$ of water per person per day for PLHIV, water services differ widely depending on the type of area in which people live, which has implications for the formulation of appropriate and effective policies and programmes. Adichie's (2009) reference of a 'single story', in which a group of people is seen in only one dominant way, as if there are no other angles or narratives that are possible, can be applied to PLHIV. For example, Campbell (2003, p. 13) states that the reality of 'very many people' living with HIV/AIDS in southern Africa seems to be one of 'deepening poverty, isolation and an inability to satisfy basic needs such as food and shelter'. While this is true, this generalisation glosses over the differing challenges faced by PLHIV in small towns, rural areas, informal settlements and formal suburbs - and the types and level of services provided.

In many parts of South Africa's metropolitan areas, water infrastructure is well developed. According to Statistics South Africa's General Household Survey of 2018, 97.7\% of the urban population in metros had access to tap water (Statistics South Africa, 2018). Central areas or formerly 'white' urban areas are well-resourced with household taps and reliable access to water. Many peri-urban areas and townships, on the other hand, have formal housing with taps in the house or in the yard, but can experience water interruptions for hours or days. Only 55\% of households report no interruptions longer than 2 days (Palmer et al., 2017). As rural areas on the fringes of cities transition to perirural areas, some households may be given yard connections (or more rarely house connections), but often face more regular or longer interruptions. While $85 \%$ of water systems are reported as functional, this is with $65 \%$ average reliability (Parliamentary Monitoring Group, 2017). Regardless of the reliability of supply, most urban households have meters, so the ability of a household to access an increased quantity of water for PLHIV depends not only on the area they live in and the quality of service provided by the municipality, but also the municipality's tariff structure and the ability of a household to pay (Smith and Hanson, 2003).

The majority of communities in informal settlements source their water from communal taps, which are typically shared by a large number of households and may be located across the settlement. The guidelines for basic levels of water supply services in South African municipalities state that a maximum of 25 households should be served by a single standpipe at a flow rate of not less than $10 \mathrm{~L} / \mathrm{min}$, which is based on the $25 \mathrm{~L} /$ person per day scale (DWAF, 2004 in Harhoff and Rieveld, 2009). It is common for communal taps in informal settlements to be damaged. In her study of water and sanitation access of PLHIV in an informal settlement in eThekwini Municipality, Mulopo (2015) found that a single functioning communal tap had to supply water to more than 100 households and people were forced to walk long distances to reach it. In locations where households had yard taps or running water in their homes, some were without water because they could not afford to pay water bills for amounts that exceeded the free basic supply. In such circumstances, household members fetch water from their immediate neighbours. It was reported that some neighbours at times refused to supply water or charged for it (Mulopo, 2015).

Coverage in rural areas seems to have improved gradually, from approximately $20 \%$ to about $60-70 \%$ between 1985 and 2010 (AMCOW, 2011); an estimated 35\% of all people lack access to clean water (Frost et al., 2014; Palmer et al., 2017).
However infrastructure is typically basic; most rural areas are served by communal standpipes that may be located far from some households, often further than the standard of $200 \mathrm{~m}$ and difficult for households to access if the terrain is hilly or rough (Obi et al., 2006). In addition, this water may be of poor quality and communities face regular and sometimes lengthy interruptions in supply. In response to interruptions or a lack of infrastructure, municipalities often provide water tankers, which can be unreliable. Ultimately people may resort to the use of surface water from rivers or unprotected springs, which is affected by climatic changes. There is a high risk of contaminated water, particularly from shared use with animals or from faecal matter washing into the river upstream.

In South Africa, the bulk of AIDS care is provided within the community, with women caring for their partners and children or through home-based care workers. Women typically are responsible for accessing water (De la Porte, 2011), making the less visible costs of poor water access gendered; when water is not easily accessible, women spend a disproportionate amount of time fetching water, particularly in rural areas. Their time is also consumed by other 'reproductive roles' (Mulopo, 2015; May, 2000 in Tallis, 2002), such as child care, helping children with homework, preparing meals and nurturing (Fajarwati et al., 2016). This is compounded when women living with HIV must also take care of their partner and/or sick child, while being ill themselves. However it is important to note that this gendered burden is often embedded in household relations; so even if the burden for accessing water or caring for household members is lightened, women's labour and time is typically reallocated to another task such as agriculture, additional work related to the household, or errands (Galvin, 2011).

Given the direct relationship between service level and the location of households, which typically is class-related, the focus of the discussion needs to shift to improving service level as a means of increasing the quantity of water that is accessible, as illustrated by Howard and Bartram (2003, p. 22) in Table 3.

In terms of service level, studies show that being forced to travel great distances to collect water leads households to reduce their intake and use sources that are less safe (Howard and Bartram, 2003). PLHIV require a minimum service of a tap in yards or 'intermediate access' (Potter and Clacherty, 2007); access to water from a house connection reduces the incidence of diarrhoea attributable to water supply by $63 \%$ as opposed to using a public source (Cairncross and Valdmanis, 2004). Practitioners focus on addressing backlogs and interruptions, while improving the level of service according to plans set by each municipality.

So while the level of service available to PLHIV differs depending on their geographic area and social class, ensuring that water services are delivered and improving the level of service is the responsibility of municipalities. This responsibility was transferred to municipalities - many of which had recently been established - in 2000. They face the challenge of providing infrastructure, operating and maintaining water systems, collecting revenue, and communicating with residents, amongst other things. Most municipalities struggle to provide a basic service level to all users, while beginning to provide peri-urban areas with intermediate access.

However, once areas obtain intermediate access, it is the cost and affordability of water that determine the quantity of water that people can actually access. In terms of affordability, South Africa's policy since 2000 has been to provide $6 \mathrm{~kL}$ of free basic water (FBW) per month to each household, which is equivalent to $25 \mathrm{~L}$ per person per day for a household of 8 people (in some municipalities, this has now been increased to $9 \mathrm{~kL}$ ). In addition 
Table 3. Service level descriptors of water in relation to hygiene (Source: Howard and Bartram, 2003, p. 22)

\begin{tabular}{|c|c|c|c|}
\hline Service level description & Distance/time & Likely quantities collected & Level of health concern \\
\hline No access & $\begin{array}{l}\text { More than } 1000 \mathrm{~m} \text { or } 30 \mathrm{~min} \text { total } \\
\text { collection time }\end{array}$ & $\begin{array}{l}\text { Very low (often less than } 5 \mathrm{~L} \text { /person } \\
\text { per day) }\end{array}$ & $\begin{array}{l}\text { Very high. Hygiene not assured and } \\
\text { consumption needs may be at risk. } \\
\text { Quality difficult to assure: emphasis } \\
\text { on effective use and water handling } \\
\text { hygiene. }\end{array}$ \\
\hline Basic access & $\begin{array}{l}\text { Between } 100 \text { and } 1000 \mathrm{~m} \text { ( } 5 \text { to } \\
30 \text { minutes total collection time) }\end{array}$ & $\begin{array}{l}\text { Low. Average is unlikely to exceed } \\
20 \mathrm{~L} / \text { person per day; laundry and/or } \\
\text { bathing may occur at water source } \\
\text { with additional volumes of water }\end{array}$ & $\begin{array}{l}\text { Medium. Not all requirements may } \\
\text { be met. Quality difficult to assure. }\end{array}$ \\
\hline Intermediate access & $\begin{array}{l}\text { On-plot (e.g single tap in house } \\
\text { or yard) }\end{array}$ & $\begin{array}{l}\text { Medium, likely to be around } 50 \mathrm{~L} / \\
\text { person per day, higher volumes } \\
\text { unlikely as energy/time requirements } \\
\text { still significant }\end{array}$ & $\begin{array}{l}\text { Low. Most basic hygiene and } \\
\text { consumption needs met. Bathing and } \\
\text { laundry possible on-site, which may } \\
\text { increase frequency of laundering. } \\
\text { Issues of effective use still important. } \\
\text { Quality more readily assured. }\end{array}$ \\
\hline Optimal access & $\begin{array}{l}\text { Water is piped into the home } \\
\text { through multiple taps. }\end{array}$ & $\begin{array}{l}\text { Varies significantly but likely above } \\
100 \mathrm{~L} / \text { person per day and may be up } \\
\text { to } 300 \mathrm{~L} \text { /person per day. }\end{array}$ & $\begin{array}{l}\text { Very low. All uses can be met, quality } \\
\text { readily assured. }\end{array}$ \\
\hline
\end{tabular}

to criticism that FBW does not provide adequate water for large households, it does not come close to the increased quantity needed for PLHIV (Hunter, 2005; Muller, 2008). PLHIV must pay for the quantity of water that they use above the FBW amount.

Over and above the FBW amount, municipalities set tariffs and bill users for water. Tariffs are set to recover the full or partial cost of water, including infrastructure, operations and maintenace. Policy debate, intensive activism and local contestation have been sustained against cost recovery pursued by municipalities and the measures they take to collect revenue or end 'illegal connections'. Full cost recovery is one manifestation of a neoliberal economic approach, which undermines poor people's universal human right to water and the right to access to water specified in the South African Constitution. (McDonald and Ruiters, 2005; Bond and Dugard, 2008; Bakker, 2010; Sahle et al., 2019)

Few local practitioners question that cost keeps many PLHIV from accessing the quantity of water needed. For instance, Potter and Clacherty (2007, p. 4) argue that:

Households affected by HIV/AIDS need more than the basic level of services. However, most people with HIV are in the income-earning age group. Loss of income due to sickness or death from AIDS related diseases decreases a household's ability to pay for higher levels of service. Policies for the provision of free basic water and sanitation services must respond to these challenges.

Households with PLHIV need more water at the same time as they have a reduced capacity to pay for it.

The impact of neo-liberalism is evident in the work of authors such as Makaudze et al. (2012, p. 52) who maintain a position of 'user must pay', even though it seems to contradict the data they gathered as part of their study conducted with support of the Water Research Commission. Having surveyed 485 PLHIV in rural, peri-urban and informal areas across three provinces, they acknowledge the 'much greater requirement' for water for people living with advanced HIV and AIDS and recommend special consideration of ways that 'extra free water can be supplied to meet special needs of PLWHA' (Makaudze et al., 2012, p. 61, emphasis added). However their main assertion contradicts these findings, and appears to be more of an ideological statement. They assert that PLHIV should become the 'primary decision maker, investor, maintainer, organiser and overseer', and that paying for water instils a sense of ownership and responsibility.
They recommend that 'notwithstanding whether the government will subsidise water provision or not, the 'user pays principle' must be guiding principle conveyed to all users' (Makaudze et al., 2012, p. 61). It is clear that this follows from their general argument, which is common amongst policy makers supporting cost recovery, that 'the worst possible approach is to see poor people as having no resources and being entirely incapable of making contributions toward meeting their own costs for water and sanitation services that are so central to their livelihood and survival' (Makaudze et al., 2012, p. 50).

It is important to distinguish between affordability and willingness to pay. It is likely that households of PLHIV are 'willing' to pay for water because the human need to care for a sick loved one trumps all other needs, such as education or perhaps even adequate food. Their willingness to cover water costs does not indicate their ability to do so, though the situation varies from one household to another. PLHIV are still faced with many other financial commitments necessary to care for their health, such as maintaining a healthy diet, home treatment of the water, and increased living expenses (constantly changing bedding). At an advanced stage, PLHIV also face the risk of losing their income because they are laid off or have to take time off their responsibilities at work (Kamminga and Wegelin Schuringa, 2005; Seremet et al., 2010). Moreover, if the need for water can be up to 4 times as much as that provided as free basic water, the cost for households that are already financially pressured will be high.

Having considered the challenges faced by practitioners, it is now useful to turn to the South African policy context. The following section reviews how the need of PLHIV for additional water in various areas has (or has not) been incorporated into existing policy.

\section{Policy-makers: ensuring that policies and plans address the water services needs of PLHIV}

While a range of policies and plans have engaged with HIV and water to a limited degree, none have been adopted, developed or implemented. It is important to look at the two approaches taken by South African policymakers. The first approach is for state institutions to express intentions and make an effort to mainstream improved delivery of water for PLHIV into their existing work. The second approach is tasking a multi-stakeholder group with reviewing the issue and making recommendations for a strategy that can be implemented. How these unfolded in 
the context of providing adequate water to PLHIV is discussed below.

In terms of the first approach, the link between HIV and water is not emphasised in the National Strategic Plan on HIV, STIs and TB (2012-2016) (NSP), the most visible means of driving action by government. It states that HIV must be conceptualised as a development challenge, within a socio-economic context with interrelated development concerns such as basic services. The only direct reference to water is under the section on the living conditions in informal settlements (SANAC, n.d, p. 35):

The poor living conditions in informal settlements provide fertile ground for HIV, STI and TB transmission, as well as the spread of many other communicable diseases, especially among children - mainly as a result of the lack of proper building materials, the lack of access to basic services, such as sewerage, electricity and running water, and the lack of food security.

It is noted that the Department of Human Settlements has mapped all informal settlements and documented challenges including the need for improved access to basic services (SANAC, n.d, p. 35).

The NSP promotes the mainstreaming of HIV into the core mandates of all government departments at all levels, since they have a 'critical role to play in addressing the social, economic and structural factors driving these diseases' and have a constitutional obligation for the progressive realisation of the right to dignity and health, amongst others. The Department of Public Service and Administration's guidelines for mainstreaming are 'meant to sensitise national and provincial government departments to render their services in a gender sensitive and rights based manner that upholds the dignity of individuals especially those living with HIV' (DPSA, 2011, p. 4). They specify that government needs to allocate adequate human and financial resources and that HIV objectives (and indicators) need to be clearly defined and aligned to national strategies and plans (DPSA, 2011). Therefore it is up to the Department of Water and Sanitation and other relevant departments to take this plan forward.

In 2003 the Department of Water and Sanitation expressed this commitment in its Strategic Framework for Water Services: municipalities 'must take into account the impact of HIV/AIDS on water demand' (Potter and Clacherty, 2007, p. 16; DWAF, 2003, p. 22). The plans of Water Services Authorities (WSAs) to do so should appear in the municipal Integrated Development Plans (IDPs) and specific Water Services Development Plans. Potter and Clacherty (2007) outlined possible ways for WSAs to reduce the impact of HIV/AIDS, and other authors note how steps can be taken at the community level to improve water quality, such as providing options for household water treatment, storage and handling to ensure an acceptable quality of water (Magrath and Tesfu, 2006; Ashton and Ramasar, 2002; Lule et al., 2005 in Potgieter and Du Preez 2012).

Municipalities, through the South African Local Government Association (SALGA), echoed this acknowledgement of the need to engage around HIV and water (SALGA, 2008). Its policy document on IDPs acknowledges that change is needed (SALGA, 2008, p. 5):

Good sanitation has particular relevance in a context of high HIV/AIDS prevalence. The health and well-being of those infected with the HIV virus are directly affected by the quality of their living environment. Poor sanitation and water services present the risk of exposure to infectious diseases and illnesses to which HIV positive people are particularly susceptible - including diarrhoea and cholera.
Good water and sanitation services reduce a significant area of stress on the ailing immune systems of those with the virus, and can thereby support the maintenance of strong immune functioning; this in turn can extend the period before anti-retroviral treatment becomes necessary, or before people fall prey to a range of opportunistic infections which eventually prove fatal. For those who have AIDS, and for those who care for them, clean water, accessible and hygienic toilets and effective grey water disposal systems are essential. Where hospital admission is not feasible, the burden of care is shifted to the home. It is essential that basic services ease this burden as much as possible.

Yet it does not appear that this has been operationalised through action plans or changes in the provision of water services at the municipal level. A few municipal IDPs, such as Beaufort West, restate the very same goals as in the NSP, which include (but are not limited to) partnering with other stakeholders (municipalities/NGOs/community members) in fighting HIV and TB illnesses and ensuring that clean water is accessible (Beaufort West Municipalicy, 2016). Yet it considers water and HIV as separate issues rather than issues that affect each other, and has no plans of how to achieve them. While it is possible that champions within these structures are building relationships that are the basis for improved cooperation, institutionally it appears that cooperation between municipalities and the Department of Health is lacking, despite some aspirational statements about water's importance for PLHIV.

The second approach of policy makers was to formulate policy through a multi-stakeholder body. In 2007 the Water Sector Leadership Group (WSLG), a multi-stakeholder group regularly convened by the Department of Water and Sanitation, produced what is arguably the most detailed and thoughtful - and practically useful in terms of implementation - analysis of HIV and water policy. The process of drafting the 'Strategic Framework for Mainstreaming HIV and AIDs in the Water Sector' began in 2004 and was presented to the WSLG in November 2009. It is not surprising that the DWS Directorate Water Services: Policy and Strategy asked that it be referred to as a 'draft stategy' rather than a 'strategic framework'. What is proposed has wideranging financial implications, and WSLG had increasingly little influence in the sector after the Masibambane programme ended. So over the past decade, the document has not moved past the draft stage, and was not formally adopted or implemented by DWS.

This strategic framework is an impressive document, which reviews the literature and carefully considers the relationship between HIV and water. Its premise is that access to safe water and sanitation plays a key role in mitigating the impact of HIV/ AIDs. It highlights that, without access to safe water, people use rivers and unsafe sources that shorten their lives: 'diarrhoea kills' (p. 7). It moves past this acknowledgement to consider two inter-related policy approaches:

- Targeting and prioritising certain geographical areas according to agreed criteria

- Changing the 'free basic water' and water tariffs to assist PLHIV

These inter-related recommendations are best considered by examining the targeting approaches used to date: an inclusive design through the original implementation of FBW and a targeted design through the 'indigent register' used by some municipalities to implement FBW. The usefulness of these approaches and the WSLG's recommended geographical approach are discussed below.

An inclusive design in formulating programmes considers 
everyone's needs rather than targeting a specific audience (Bery and Rosenbaum, 2010). For example, in 2000 FBW was initially applied to all households in eThekwini Municipality, without targeting. To provide the $100 \mathrm{~L}$ needed by PLHIV, municipalties would have to increase the quantity of free basic water presently being provided to everyone and to ensure that the first step in their tariff structure is more affordable - for all households receiving FBW. Given the financial constraints faced by most municipalities, and many times their struggle to provide even the existing FBW amount, this scenario is highly unlikely to be implemented.

In contrast, targeting a specific audience tends to backfire as it makes households with those characteristics easy to identify within the community and subject to stigmatisation. The City of Johannesburg explored this issue in detail, concluding that it would be a 'grave invasion of privacy' to ask people to disclose their status (Eales, 2017). Paradoxically, targeting poor households is already in place in many municipalities (including the City of Johannesburg), where 'indigent' households are required to present proof of 'indigence' to the municipality in order to to access FBW. So, if a municipality chooses to increase the amount of water provided to PLHIV, targeting could theoretically work in places where households are billed (metros and towns). With a revised indigent policy, households could register as 'indigent with a PLHIV' and the free basic water amount could be increased and/ or they could be charged a reduced tariff for the quantity of water over the FBW amount. Aside from municipal budget constraints, this also raises issues of privacy.

While others focus on targeting areas with a proportionately high number of PLHIV (West et al., 2013), the WSLG proposed narrowing this further by targeting 'high prevalence areas' with poor access to basic water services. Here they would address backlogs and provide FBW and FBS. Areas were prioritised in the following order (DWA, 2007: section 3, p. 5):

1. Informal settlements (high poverty, low levels of service, highest infection rates)

2. Reliance on rivers/streams

3. Low levels of water services provision

4. High poverty and high prevalence

5. High poverty and low levels of service provision

Improving service levels in informal settlements and rural areas would mean decreasing the distance of standpipes from households so that they can access more water and ensuring safe water is used.

In summary, there has been recognition of the issue within the health and water sectors, but no further development of action plans or implementation of changes has followed. A promising strategic framework document developed by a multi-stakeholder group convened by the Department of Water and Sanitation was shelved by the same department for budget reasons or possibly due to political dynamics (Galvin and Roux, 2019). The document specified the importance of investing in and improving service levels in targeted areas, setting tariffs to subsidise services for the most vulnerable, and regulating providers to ensure that vulnerable communities have access to adequate and affordable quantities of water. It drew together considerations of researchers, practitioners and policy-makers into a single approach.

\section{CONCLUSION}

The need of PLHIV to access an adequate amount of safe water places increased physical, financial, time and/or psychological demands on them and their households (WaterAid, 2010). This article has reviewed detailed studies that capture the experience of caregivers and quantified the water required for various needs as up to $100 \mathrm{~L} /$ person per day. It has grappled with differences between geographical areas and suggested ways that practitioners can use this estimation as a catalyst to improve service levels, although the questions of affordability remain. Finally the article showed how policy makers expressed their desire to address the need of PLHIV for improved water services, but when a strategy was crafted through a multi-stakeholder process to implement this commitment, it was not taken up by DWS. Practitioners continued business as usual: installing systems, improving service levels, and attending to operations and maintaince issues as needed in different areas.

Since water is required for all kinds of care, our analysis extends to other diseases, aging populations, climate displacement, and other situations that 'stretch' basic water needs. Policy makers must therefore increasingly reckon with a flexible and growing 'normal' demand, which may arguably necessitate increasing the quantity of free water provision for all.

A range of questions arise that require further research. First, around the same time that the multi-stakeholder strategy was drafted, academic literature began to explore the complex relationship between poverty and HIV (Shelton et al., 2005; Nattrass 2009; Parkhurst, 2010). Very generally analyses find that there is no statistically significant relationship between poverty and people contracting HIV. However poverty does make people more vulnerable to the effects of HIV, as they cannot access clinics easily and may not have adequate food to minimise the side effects of ARVs. Understanding the complex relationship between poverty and HIV can better inform support provided to PLHIV. Similarly the widespread roll-out of ARVs has changed the context, and the water needs of PLHIV need to be reassessed.

How can data collection be improved so that there is a deeper understanding of local dynamics related to the needs of specific populations and sufficient data to model nuanced policy responses? While DWS and municipalities do collect data, incentives to ensure data accuracy are absent as people know that data has implications for funding and profiling of municipalities. Here there is potential for researchers and civil society organisations to contribute to data collection prior to situations requiring urgent policy responses. Research is needed to review data collection and management systems in South Africa and those in comparable contexts in other countries, and to consider creative means of improving them.

Systemic questions also arise in relation to municipalities' inaction in formulating specific plans to meet the water needs of PLHIV. Further research is needed to assess whether the water needs of PLHIV have been considered as part of Water Services Development Plans and, if so, whether the lack of action is due to challenges of implementation or a lack of national guidance, support and regulation.

Finally, research is needed to explore what groups might act as a successful external source of pressure at the municipal level, as a direct incentive for the implementation of policies and guidelines. NGOs and social movements typically play that role. For example, the Treatment Action Campaign (TAC) achieved its aim of obtaining free antiretrovirals from government through a mixture of engagement and protest (Heywood, 2009), as evident in its own account of its extensive advocacy work:

TAC believes that the right to quality and affordable health care for all people is a basic right, along with the right to dignity, equality and life. In line with this, TAC campaigned for the prevention and elimination of HIV infections, and for equitable and affordable access to treatment, campaign and support; it advocated for and promoted legislation that supported these rights and it trained representative and effective leadership that could drive campaigns and struggles. All the actions of TAC were directed towards 
improving health, particularly amongst poor and working class people. The original TAC mandate in the late 1990s was built on activism and lobbying with clear aims and objectives. During this period the TAC played a key role in changing mindsets and forcing action from Government towards HIV and AIDS. Over a decade the TAC has broadly achieved its original objectives and this could be seen through the renewed Government approach to HIV and AIDS in South Africa (TAC, 2010).

In terms of possible advocacy emanating from within the water sector, the commitment of activists from the Anti-Privatisation Forum (APF) was evident in their driving of the Mazibuko case all the way to the Consitutional Court (Bond and Dugard, 2008; Sahle et al., 2019). However the APF has subsequently folded and there is no sign of a group with the interest and capacity to take up the issue of adequate provision of water for PLHIV.

Multi-stakeholder groups such as the Water Sector Leadership Group or the Water Dialogues in South Africa's water sector might provide an option (Galvin, 2016). While the involvement of stakeholders was encouraged in the 1990s and 2000s through the Masibambane programme and its sector support approach, it now tends to be ignored or sidelined. Research with DWS officials could examine their perceptions of multi-stakeholder input and its utility, and barriers to its use. Research could also examine means of bringing in outside influence through coordinated engagement by donors or other oversight bodies.

Whether the intentions of researchers and activists, practitioners, and policy makers have failed in meeting the water services needs of PLHIV is open to interpretation. Most cynically, amidst many efforts and extensive discussion, business has carried on as usual. Conundrums of contention around financing and free services remain unresolved. However, by trying to meet the challenge of providing water for PLHIV, the resolve and commitment of all actors to achieve or surpass existing aims was arguably strengthened. They were forced to revisit and acknowledge the deeper challenges masked by business as usual, moving from policy to action and seeing what otherwise remains invisible.

\section{REFERENCES}

ADICHIE C (2009) The danger of a single story-TED Ideas worth spreading. URL: www.ted.com/talks/chimamanda_adichie_the_ danger_of_a_single_story/transcript?language $=$ en (Accessed $2 \overline{2}$ March 2015).

AKETCH CO (2017) The burden of water, sanitation and hygiene on people living with HIV/AIDS in Kibera slum. Masters Thesis, Jomo Kenyatta University of Agriculture and Technology.

AMCOW (2011) Water supply and sanitation in South Africa: Turning finance into services for 2015 and beyond. URL: https://wsp.org/ sites/wsp.org/files/publications/CSO-SouthAfrica.pdf (Accessed 8 April 2017).

ASHTON P and RAMASAR V (2002) Water and HIV/AIDS: Some strategic considerations in Southern Africa. In Turton AR and Henwood R (eds.) Hydropolitics in the Developing World: A Southern African Perspective. African Water Issues Research Unit (AWIRU), Pretoria. URL: http://www.anthonyturton.com/assets/ my_documents/my_files/ASHTON\&Ramasar-HIVAIDS_Chapter. pdf (Accessed 27 July 2017). 217-235.

BAKKER K (2010) Privatizing Water: Governance Failure and the World's Urban Water Crisis. Cornell University Press, Ithaca, NY.

BEAUFORT WEST MUNICIPALITY (2016) WSDP - IDP water sector input report (executive summary). URL: https://www. beaufortwestmun.co.za/download_document/794 (Accessed 22 April 2017).

BENNETT O (1990) Triple Jeopardy: Women and AIDS. Panos Institute, London. URL: www.aegis.com/pubs/panos/1990/Triple_Jeopardy_ Women_and_AIDS.asp (Accessed 14 October 2016).

BERY R and ROSENBAUM J (2007) Analysis of research on the effects of improved water, sanitation, and hygiene on the health of people living with HIV and AIDS and programmatic implications- Review by Kate Tulenko. URL: https://www.ircwash.org/sites/default/files/ Tulenko-2007-Analysis.pdf (Accessed 27 April 2017).

BERY R and ROSENBAUM J (2010) How to integrate water, sanitation and hygiene into HIV programmes- World Health Organisation, Geneva. URL: http://apps.who.int/iris/ bitstream/10665/44393/1/9789241548014_eng.pdf (Accessed 11 April 2017).

BOND P and DUGARD J (2008) The case of Johannesburg Water: What really happened at the pre-paid 'Parish pump'. Law Democr. Dev. 12 (1) 1-28. https://doi.org/10.4314/ldd.v12i1.52878

CAIRNCROSS S and VALDMANIS V (2004) Water supply, sanitation and hygiene promotion. Disease Control Priorities Project, Working Paper no. 28. URL: http://researchonline.lshtm.ac.uk/12970/1/ Water\%20supply,\%20sanitation\%20and\%20hygiene $\% 20$ promotionDisease $\% 20$ Control\%20Priorities $\% 20$ Project, $\% 20$ Working\%20Paper\%20no.\%2028.pdf (Accessed 10 June 2017).

CAMPBELL C (2003) Letting Them Die: Why HIV/AIDS Intervention Programmes Fail. Indiana University Press, Bloomington. https:// doi.org/10.1136/sbmj.0312439

DE LA PORTE S (2011) HIV/AIDS, care-giving and the politics of water and sanitation: A case study. Agenda 25 (2) 103-112. https://doi.org/ $10.1080 / 10130950.2011 .576003$

DPSA (Department of Public Service and Administration, South Africa) (2011) Guidelines on gender sensitive and rights based HIV \& AIDS, STIs and TB mainstreaming into public administration and public service 2012-2016. URL: http://www.dpsa.gov.za/dpsa2g/ documents/ehw/policy/Gender\%20Sensitive3Sept25.pdf (Accessed 8 April 2017).

DWAF (Department of Water Affairs and Forestry, South Africa) (2003) Strategic framework for water services. URL: http://www.dwaf.gov. za/Documents/Policies/Strategic\%20Framework\%20approved.pdf (Accessed 7 June 2017).

DWAF (Department of Water Affairs and Forestry, South Africa) (20078) Strategic framework for mainstreaming HIV and AIDS in the water sector, Part C. URL: http://www.dwa.gov.za/Masibambane/ documents/hivaids/DWAF\%20HIVAIDS\%20Revised\%20 Project\%20Plan2.pdf (Accessed 8 April 2017).

EALES K (2017) Personal communication, 10 March 2017. Kathy Eales, independent consultant, kea@iafrica.com.

FAJARWATI A, MEI ETW, HASANATI S and SARI IM (2016) The productive and reproductive activities of women as form of adaptation and post-disaster livelihood strategies in Huntap Kuwang and Huntap Plosokerep. Proced. Soc. Behav. Sci. 227 370-377. https:// doi.org/10.1016/j.sbspro.2016.06.084

FROST B, BAIN C, SIMMS B and CHINGANDU L (2014) HIV/Aids cannot be beaten without water. The Guardian. URL: https://www. theguardian.com/society/2014/nov/30/hiv-aids-cannot-be-beatenwithout-water (Accessed 8 March 2018).

GALVIN M (2011) Participating in urban myths about women's rural water struggles. Agenda 25 (2) 87-100. https://doi.org/10.1080/1013 0950.2011 .576001

GALVIN M (2016) Leaving boxes behind: civil society and water and sanitation struggles in Durban, South Africa. Transform. Crit. Perspect. South. Afr. 92 (1) 111-134. https://doi.org/10.1353/ trn.2016.0029

GALVIN M and ROUX S (2019) Dam state capture: its cascading effect on the Department of Water and Sanitation. Transform. Crit. Perspect. South. Afr. 100 (1) 153-178. https://doi.org/10.1353/trn.2019.0026

GOSLING L (2015) World Water Day 2015: The role of water in HIV support. URL: http://www.angloamerican.com/media/our-stories/ world-water-day-2015 (Accessed 8 March 2018).

HAARHOFF J and RIETVELD L (2009) Public standpipe design and maintenance for rural South Africa. J. S. Afr. Inst. Civ. Eng. 51 (1) $6-14$.

HEYWOOD M (2009) South Africa's Treatment Action Campaign: combining law and social mobilization to realize the right to health. J. Hum. Rights Pract. 1 (1) 14-36. https://doi.org/10.1093/ jhuman/hun006

HOWARD G and BARTRAM J (2003) Domestic water quantity, service level, and health. URL: https://www.ircwash.org/sites/default/files/ Howard-2003-Domestic.pdf (Accessed 7 June 2017).

HUNTER N (2005) An assessment of how government's care policy 
is working in practice: Findings from KwaZulu-Natal. School of Development Studies, Durban: University of KwaZulu-Natal.

IRC INTERNATIONAL WATER AND SANITATION CENTRE (2007) Caring for HIV: Infected people in South Africa need love, patience and $200 \mathrm{~L}$ of water per day. IRC Bulletin No 48. URL: www.irc.nl/ content/download/129024/.../SourceBulletin48-2007.pdf (Accessed 22 August 2013).

KAMMINGA E and WEGELIN-SCHURINGA M (2005) HIV/AIDS and water sanitation and hygiene: Thematic overview paper. IRC International Water and Sanitation Centre, Delft. URL: http://www. irc.nl/page/3462 (Accessed 4 May 2017).

KGALUSHI R, SMITS S and EALES K (2004) People living with HIV/ AIDS in the context of rural poverty - the importance of water and sanitation services and hygiene education: A case study from Bolobedu (Limpopo Province, South Africa). URL: http://citeseerx. ist.psu.edu/viewdoc/download?doi=10.1.1.547.6914\&rep=rep1\&typ e=pdf (Accessed 27 July 2017).

KIONGO JM (2005) The Millennium Development Goal on poverty and the links with water supply, sanitation, hygiene and HIV/AIDS a case study from Kenya. IRC International Water and Sanitation Centre, Delft. URL: http://www.irc.nl/page/16127 (Accessed 22 August 2013).

LULE JR, MERMIN J, EKWARU JP, MALAMBA S, DOWNING $R$, RANSOM R, NAKANJAKO D, WAFULA W, HUGHES $P$, BUNNELL R and KAHARUZA F (2005) Effect of home-based water chlorination and safe storage on diarrhea among persons with human immunodeficiency virus in Uganda. Am. J. Trop. Med. Hyg. 73 (5) 926-933. https://doi.org/10.4269/ajtmh.2005.73.926

MAGRATH P and TESFU M (2006) Meeting the needs for water and sanitation of people living with HIV/AIDS in Addis Ababa, Ethiopia. URL: http://www.wateraid.org/documents/plugin_documents/ hivaids_equal_access_for_all_no._6_april_2006.pdf (Accessed 22 August 2016).

MAKAUDZE E, DU PREEZ M and POTGIETER N (2012) How does the HIV and AIDS epidemic in South Africa impact on water, sanitation and hygiene sectors?. WRC Report No. 1813/1/11. Water Research Commission, Pretoria.

MANASE G, NKUNA Z and NGORIMA E (2009) Using water and sanitation as an entry point to fight poverty and respond to HIV/ AIDS: The case of Isulabasha Small Medium Enterprise. Phys. Chem. Earth A/B/C 34 (13) 866-873. https://doi.org/10.1016/j pce.2009.07.007

MBEREKO A, SCOTT D and CHIMBARI MJ (2016) The relationship between HIV and AIDS and water scarcity in Nyamakate resettlements land, north-central Zimbabwe. Afr. J. AIDS Res. 15 (4) 349-357. https://doi.org/10.2989/16085906.2016.1247735

MCDONALD D and RUITERS G (2005) The Age of Commodity: Water Privatization in Southern Africa. Earthscan Press, London.

MIS M (2014) Lack of access to clean water hampers fight against AIDS in Africa -TRFN. URL: http://www.reuters.com/article/aids-africawater/lack-of-access-to-clean-water-hampers-fight-against-aids-inafrica-trfn-idUSL6N0TL2K820141201 (Accessed 8 March 2018).

MULLER M (2008) Free basic water-a sustainable instrument for a sustainable future in South Africa. Environ. Urbanization 20 (1) 67-87. https://doi.org/10.1177/0956247808089149

MULOPO C (2015) Water, sanitation and hygiene in community and home-based care for people living with HIV/AIDS/TB in Durban, South Africa. Masters Dissertation, University of Kwazulu-Natal.

NATTRASS N (2009) Poverty, sex and HIV. AIDS Behav. 13 833-840. https://doi.org/10.1007/s10461-009-9563-9

NGWENYA BN and KGATHI DL (2006) HIV/AIDS and access to water a case study of home-based care in Ngamiland, Botswana. Phys. Chem. Earth A/B/C 31 (15) 669-680. https://doi.org/10.1016/j. pce.2006.08.041

NKONGO D and CHONYA C (2009) Access to water and sanitation for people living with HIV and AIDS: an exploratory study. Water Aid and AMREF. URL: www.wateraid.org/ /media/Publications/accesswater-sanitation-hiv-aids-tanzania.pdf (Accessed 27 July 2017).

OBI CL, ONABOLU B, MOMBA MNB, IGUMBOR JO, RAMALIVAHNA J, BESSONG PO, VAN RENSBURG EJ, LUKOTO M, GREEN E and MULAUDZI TB (2006) The interesting crosspaths of HIV/AIDS and water in Southern Africa with special reference to South Africa. Water SA 32 (3) 323-343. https://doi. org/10.4314/wsa.v32i3.5277

PALMER I, MOODLEY N and PARNELL S (2017) Building a Capable State in Post-Apartheid South Africa. UCT Press, Cape Town.

PARKHURST JO (2010) Understanding the correlations between wealth, poverty and human immunodeficiency virus infection in African countries. Bull. World Health Organ. 88 519-526. https:// doi.org/10.2471/BLT.09.070185

PARLIAMENTARY MONITORING GROUP (2017) Water \& Sanitation: Statistics SA analysis. URL: https://pmg.org.za/ committee-meeting/23868/ (Accessed 12 January 2020).

POTGIETER N and PREEZ M (2012) Health impact of water, sanitation and hygiene services in relation to home-based care for people living with HIV and AIDS in the Limpopo Province, South Africa, WRC Report No. 1738/1/1. Water Research Commission, Pretoria.

POTGIETER N, KOEKEMOER R and JAGALS P (2007) A pilot assessment of water, sanitation, hygiene and home-based care services for people living with HIV/AIDS in rural and peri-urban communities in South Africa. Water Sci. Technol. 56 (5) 125-131. https://doi.org/10.2166/wst.2007.564

POTGIETER N, POTGIETER R and JAGALS P (2008) Impacts of the provision of water, sanitation, hygiene and home based care services to HIV and AIDS infected people, WRC Report No. KV 209/08. Water Research Commission, Pretoria.

POTTER A and MOLOSE M (2005) Access to clean water crucial in fight against AIDS. The Water Wheel 4 (6) 18-20.

POTTER A (2006) Water, sanitation and HIV/AIDS. URL: http://www. mvula.co.za/page/539 (Accessed 22 August 2013).

POTTER A and CLACHERTY A (2007) Water services and HIV/AIDS: Integrating health and hygiene education in the water and sanitation sector in the contexts of HIV/AIDS. URL: https://www.ircwash.org/ sites/default/files/Potter-2007-Water-Report.pdf (Accessed 27 June 2017).

RAMIREZ-ORTIZ D and ZOLNIKOV TR (2017) A qualitative study on the interconnected nature of HIV, water, and family. AIDS Behav. 21 (3) 803-811. https://doi.org/10.1007/s10461-016-1334-9

RITCHIE H and ROSER M (2020) Clean water. URL: https:// ourworldindata.org/water-access (Accessed 11 January 2020).

SOUTHERN AFRICA HIV AND AIDS INFORMATION DISSEMINATION SERVICE AND WATERAID (2014) Integrated approach to HIV and water, sanitation and hygiene in Southern Africa. URL: http://catalogue.safaids.net/sites/default/files/ publications/Integrated\%20approach $\% 20$ to $\% 20$ HIV\%20and $\% 20$ water\%20sanitation.pdf (Accessed 8 March 2018).

SAHLE E, GALVIN M, PIERCE B and TODD K (2019) The UN's human right to water in the context of new water governance regimes in South Africa and Tanzania. In: Sahle E (ed.) Human Rights in Africa. Palgrave Macmillan, London. https://doi. org/10.1057/978-1-137-51915-3_10

SEREMET C, WARNER D, SENEFELD S, SIMPSON-HERBERT M, MILLER C and OVERTON J (2010) Water, sanitation, and hygiene considerations in home-based care for people living with HIV. Catholic Relief Services, Baltimore, MD, USA.

SHELTON JD, CASSELL MM and ADETUNJI J (2005) Is poverty or wealth at the root of HIV?. The Lancet 366. https://doi.org/10.1016/ S0140-6736(05)67401-6

SHRESTHA RK, MARSEILLE E, KAHN JG, LULE JR, PITTER C, BLANDFORD JM and MERMIN J (2006) Cost-effectiveness of home-based chlorination and safe water storage in reducing diarrhea among HIV-affected households in rural Uganda. Am. J. Trop. Med. Hyg. 74 (5) 884-890. https://doi.org/10.4269/ajtmh.2006.74.884

SMITH L and HANSON S (2003) Access to water for the urban poor in Cape Town: where equity meets cost recovery. Urban Stud. 40 (8) 1517-1548. https://doi.org/10.1080/0042098032000094414

SALGA (South African Local Government Association) (2008) Annual Report 2008/09. URL: https:/salga.org.za/Documents/ Documents\%20and\%20Publications/Annual\%20Reports/ SalgaAnnualReport2008-09.pdf (Accessed 7 June 2017).

SALGA (South African Local Government Association) (2008) A strategic agenda for the development of a National Sanitation Policy Framework in South Africa: Concept Paper. URL: https://salga. org.za/Documents/Knowledge\%20Hub/SALGA\%20Position\%20 Papers/SALGA-Sanitation-Policy-Concept-Paper-V3-(4).pdf (Accessed 10 June 2017). 
SALGA (South African Local Government Association) (n.d.) Documents and Publications: Annual reports. URL: https://www. salga.org.za/Documents\%20and\%20Publications\%20AR.html (Accessed 9 June 2017).

SANAC (South African National Aids Council) (2012) National Strategic Plan on HIV, STIs and TB, 2012-2016. URL: http://www. doh.gov.za/docs/stratdocs/2012/NSPfull.pdf (Accessed 3 May 2017).

SANAC (South African National Aids Council) (n.d) Let our actions count: reflections on NSP 2012-2016 and moving forward to NSP 2017-2022. URL: http://nsp.sanac.org.za/wp-content/ uploads/2017/01/Final-NSP-Document.pdf (Accessed 8 April 2017).

STATISTICS SOUTH AFRICA (2018) General Household Survey. URL: http://www.statssa.gov.za/publications/P0318/P03182018.pdf (Accessed 12 January 2020).

TALLIS V (1998) AIDS is a crisis for women. Agenda 14 (39) 6-14.

TALLIS VA (2002) Gender and HIV and AIDS: cutting edge pack overview report. Institute of Development Studies, Brighton. URL: http://www.bridge.ids.ac.uk/sites/bridge.ids.ac.uk/files/reports/ CEP-HIV-reportw2.doc (Accessed 3 May 2017).

TAC (Treatment Action Campaign) (2010) Fighting for our lives: The history of the Treatment Action Campaign 1998-2010. URL: http:// www.tac.org.za/files/10yearbook/files/tac\%2010\%20year\%20draft5. pdf (Accessed 10 April 2017).

UNAIDS (United Nations Programme On HIV and AIDS (UNAIDS) (2004) Women and HIV/AIDS: Confronting the crisis. Report. URL: https://gcwa.unaids.org/sites/womenandaids.net/files/UNAIDSUNFPA-UNIFEM-WomenAids---Confronting-the-Crisis.pdf (Accessed 11 April 2017)

UNICEF (United Nations Children's Fund) (2001) Teacher's guide for the integrated water, sanitation and hygiene education, and HIV/AIDS for Grades 1 to 7. URL: http://www.schoolsanitation. org/Resources/Readings/Zambia_teachersguide\%5B1\%5D.pdf (Accessed 23 August 2013).

UN-HABITAT (United Nations Human Settlements Programme) (2006) HIV/AIDS checklist for water and sanitation projects. URL: www. unhabitat.org/pmss/getElectronicVersion.aspx?nr=2068\&alt=1
(Accessed 22 August 2013).

VAN WIJK C (2003) HIV/AIDS and water supply, sanitation and hygiene. URL: http://www.lboro.ac.uk/well/resources/fact-sheets/ fact-sheets-htm/hiv-aids.htm (Accessed 22 August 2013).

WATERAID (2004) Making the links: Mapping the relationship between water, hygiene and sanitation, and HIV/AIDS: a joint think-piece by WaterAid Ethiopia and Progynist. Water Aid, London. URL: http:// www.wateraid.org/ /media/Publications/water-sanitation-hygieneprovision-aids.pdf (Accessed 12 August 2016).

WATERAID (2010) Access to water, sanitation and hygiene for people living with HIV and AIDS: A cross-sectional study in Nepal. URL: http://www.wateraid.org/ /media/Publications/access-watersanitation-hiv-aids-nepal.pdf (Accessed 10 April 2017).

WSSCC (Water Supply and Sanitation Collaborative Council) (2009) HIV/AIDS \& WASH Reference Note. URL: http://www.wsscc.org/ sites/default/files/publications/WSSCC_Reference_Note_HIV_ AIDS_2009.pdf (Accessed 25 August 2013).

WELL PROJECT (2004) The HIV/AIDS Millennium Development Goal: HIV/AIDS and water supply, sanitation and hygiene in Southern Africa. URL: http://www.lboro.ac.uk/well/resources/Publications/ Briefing\%20Notes/WELL\%20HIV\%20Poster\%20Southern\%20 Africa\%20NC.pdf (Accessed 23 August 2013).

WEST BS, HIRSCH JS and EL-SADR W (2013) HIV and H 2 O: tracing the connections between gender, water and HIV. AIDS Behav. 17 (5) 1675-1682. https://doi.org/10.1007/s10461-012-0219-9

WORKMAN CL and UREKSOY H (2017) Water insecurity in a syndemic context: Understanding the psycho-emotional stress of water insecurity in Lesotho, Africa. Soc. Sci. Med. 179 52-60. https:// doi.org/10.1016/j.socscimed.2017.02.026

WHO (World Health Organisation) (2003) Domestic water quantity, service level and health. URL: http://www.who.int/water sanitation_health/diseases/WSH0302.pdf (Accessed 10 April 2017).

WHO (World Health Organisation) (2007) How to integrate water, sanitation and hygiene into HIV/AIDS Programmes. URL: http:// whqlibdoc.who.int/publications/2010/9789241548014_eng.pdf (Accessed 25 August 2013). 